\title{
TRACE METALS IN CANCER PATIENTS AND THEIR CORRELATION WITH RENAL FUNCTION
}

\author{
Majhi S*, Toora B D*, Sen S K*, Anantha K*, Anantha N*
}

\section{ABSTRACT}

Two trace elements, copper $(\mathrm{Cu})$ and zinc $(\mathrm{Zn})$ in serum are elevated in cancer patients since both are constituents of super oxide dismutase (SOD) as metalloenzyme, the enzyme that scavenge free radicals and activated oxygen species in the body. The study of 52 cancer patients comprising of 31 carcinoma stomach and 21 breast cancer showed the elevation of both of these trace elements in serum when compared to 32 healthy controls and effected the kidney functions as a consequences. Serum $\mathrm{Cu}$ and $\mathrm{Zn}$ were estimated by Atomic Absorption Spectrometer (AAS), analyzed statistically by student " $t$ " test and marked elevation was observed in cancer patient compared to healthy controls. Serum $\mathrm{Cu}$ and $\mathrm{Zn}$ values were $98.13 \pm 17.49$ $\mu \mathrm{g} / \mathrm{dl} 99 . .57 \pm 13.91 \mu \mathrm{g} / \mathrm{dl}$ respectively in 38 healthy subjects and these trace metals were $156.23 \pm 31.02 \mu \mathrm{g} /$ dl and $171.86 \pm 35.15 \mu \mathrm{g} / \mathrm{dl}$ in 52 cancer patients showing significant elevation $(\mathrm{P}<0.001)$. These elevated elements were routed through kidneys and damaged nephrons since both of them are cationic heavy metals. Nephrotoxicity of these trace metals was reflected as elevated level of blood urea and creatinine and were found to be $27.44 \pm 7.72 \mathrm{mg} / \mathrm{dl}$ and $0.83 \pm 0.30 \mathrm{mg} / \mathrm{dl}$ in control groups and $64.49 \pm 49 \mathrm{mg} / \mathrm{dl}$ and $1.60 \pm 0.72$ $\mathrm{mg} / \mathrm{dl}$ in cancer patients respectively, a significant elevation $(\mathrm{P}<0.001)$ in study group. The elevation of these parameters may indicate renal origin.

Key Words: Serum copper, serum zinc, super oxide dismutase, carcinoma stomach, carcinoma breast and nephrotoxicity.

\section{INTRODUCTION}

Copper $(\mathrm{Cu})$ and zinc $(\mathrm{Zn})$ are established essential trace elements and act as integral component of metalloenzymes. $\mathrm{Cu}$ containing metalloenzymes are crucial in iron and catecholamine metabolism, synthesis of hemoglobin, elastin and collagen. As a part of metalloenzyme super oxide
dismutase(SOD), $\mathrm{Cu}$ play the role in scavenging activated oxygen species(AOS) and free radicals. Many pathological conditions, particularly of cancer has been attributed to raised level of $\mathrm{Cu}$ in serum. ${ }^{1,2,3}$ Essentiality of $\mathrm{Zn}$ in living being also is well recognised. This is a important trace element that supervise many metabolic activities e.g. protein synthesis and degradation, synthesis of nucleic acid, acid base balance

* B.P. Koirala Institute of Health Sciences, Dharan, Nepal.

** J.I.P.M.E.R., Pondicherry.

*** All India Institute of Public Health and Hygiene, Calcutta.

Address for correspondence : Dr. Shankhar Majhi

Dept. of Biochemistry

B.P. Koirala Institute of Health Sciences, Dharan, Nepal.

Email: majhiis@yahoo.co.in 
including formation of insulin. This is a powerful antioxidant by virtue of participation in the formation of SOD, a $\mathrm{Cu}-\mathrm{Zn}$ containing metallo-enzyme, thus has ability to protect the cell organelles and tissues from AOS and free radicals damage ${ }^{4}$ There are reports, $\mathrm{Zn}$ levels in serum is elevated in cancer patients $^{5,6}$.As a consequence of elevated serum levels of $\mathrm{Cu}$ and $\mathrm{Zn}$, there may be renal damage since these heavy metals passes through renal tubules leading to impairment of renal functions. As a result, proportionate amount of urea and creatinine are elevated in serum of these patients.

\section{PATIENTS AND METHODS}

This is a hospital based study conducted at JIPMER Hospital, Pondicherry. The study group consisted of 52 patients, 31 had carcinoma stomach and 21 breast cancer, of which 26 were male and 26 were female. The control group consisted of 38 healthy subjects of which were 24 male and 14 female. The mean age in study group was 51.07 years, it was 36.36 years in controls. The patients and control groups were all in the same socio-economic status and had similar dietary habits. This study was designed to investigate the influence of elevated $\mathrm{Cu}$ and $\mathrm{Zn}$ in cancer patients on renal damage.

Procedure: Blood sample were collected from patients and control groups at $8.00 \mathrm{hr}$ to prevent circadian influence. Utmost care was taken to avoid haemolysis. Plastic, disposable syringe were used to limit trace metal contamination if any. The serum were separated within 2 hrs after blood withdrawal. Blood urea and creatinine along with other routine parameters were estimated by autoanalyser (Ciba Corning 550 express). Serum for $\mathrm{Cu}$ and $\mathrm{Zn}$ estimation, were stored at $-20^{\circ} \mathrm{C}$ until analysed. Both the trace element were measured by atomic absorption spectrophotometer (AAS) model 1475 series and values were expressed in $\mu \mathrm{g} / \mathrm{dl}$.

Statistical analysis : Comparative analysis was done using student " $t$ " test. Serum concentration of $\mathrm{Cu}$ and $\mathrm{Zn}$ as well as blood urea and creatinine in patients were compared with that of healthy controls.

\section{RESULT}

The serum $\mathrm{Cu}$ and $\mathrm{Zn}$ values are shown in Table I. Serum $\mathrm{Cu}$ and $\mathrm{Zn}$ level of $156.23 \pm 31.02 \mu \mathrm{g} / \mathrm{dl}$ and $171.86 \pm 35.18 \mu \mathrm{g}$ $/ \mathrm{dl}$ in cancer patients were compared with control values of $98.13 \pm 17.49 \mu \mathrm{g} / \mathrm{dl}$ and $99.57 \pm 13.91 \mu \mathrm{g} / \mathrm{dl}$ respectively. Trace metal values in individual cancers e.g. carcinoma stomach and breast cancer were also compared with control groups and result mentioned in the table I. Serum $\mathrm{Cu}$ and $\mathrm{Zn}$ in cancer patients were raised significantly $(\mathrm{P}<0.001)$.

Table I : Serum $\mathrm{Cu}$ and $\mathrm{Zn}$ levels in cancer patients $(\mathrm{n}=52)$ and control groups $(n=38)$ expressed as MEAN \pm SD

*statistically significant, $p<0.001$ 